\title{
UKRAINIAN AND ENGLISH VERBS: BILATERAL CONTRASTIVE CROSS-LINGUISTIC PERSPECTIVE
}

\author{
Natalia Ivanytska \\ Vinnytsia Institute of Trade and Economics of Kyiv National University of Trade and Economics, \\ Vinnytsia, Ukraine \\ pyasta3@gmail.com \\ Nina Ivanytska \\ Vinnytsia Mykhailo Kotsiubynskyi State Pedagogical University, Vinnytsia, Ukraine \\ pyasta4@gmail.com
}

\begin{abstract}
The paper focuses on the contrastive analysis procedure from the bilateral perspective. This work is relevant due to current crosslinguistic approaches aimed at the comprehensive study of the notional words being the central ones with their ability to express a variety of categorical meanings. The verb is viewed as a central word in Ukrainian and English being of scholars' interest for a long time. Bilateral contrastive study is believed to be an effective tool for identifying similarities and differences within the subsystems of Ukrainian and English verbs. The authors present grounds for revealing a number of benefits of comparing language units from bilateral perspective. The two-way contrastive analysis is considered to be scientifically valid when using a reasonable tertium comparationis. The latter is viewed as an objective extra-lingual basis that has a specific realisation in each language. When studying verb's systems as complicated language items the choice of tertium comparationis turns next to a verb's category "process". The predominant advantage of this category is accounted for its universal, cross functional, broad-based nature. Comprising semantic and grammatical aspects, the category of "process" is believed to be a key point for building semantic and syntagmatic paradigms in the verb's system. The study concludes that the category of "process" is qualified as generalised construct (model) comprising lexical semantics of verbs, and a set of grammatical (morphological, derivational, syntactic) categories. The realisation of verbal processing is represented by the unique combinations of forms in each of the compared languages. The specificity of the verb's category of "process" in the compared languages reveals the hidden facts that are believed to enrich the theory of language with new generalisations.
\end{abstract}

Keywords: Ukrainian and English verb's systems; contrastive linguistics; bilateral contrastive analysis; tertium comparationis; universal verb's category "process".

\section{Introduction}

Contemporary linguistics tends to identify the verb as a universal language phenomenon. The scholars who put emphasis on the verb as a central language unit believe that it has specific lexical and grammatical semantics, syntactic capacity, functional diversity, as well as systemic and level-to-level relationships with other linguistic units (Aarts \& Meyer, 2006; Baker, 2003; Ivanytska, 2011; Palmer1987). The verb is considered to have functional priority over all other parts of speech (Levin \& Rappoport, 2005: Plungyan, 1998). The verb-oriented syntax theories are still relevant for linguistic development (Sylemanova, 2015).

The categorical meaning of the verb reflects the denotatum of actions/states that human beings categorise and classify in their minds. The verb comprises a variety of grammatical aspects. The scholars claim that different languages have different ways of lexicalising verb-based meanings, most notably by means of other, divergent verb constructions (Haspelmat, 2016, p. 293). Hence, the verb has always provoked the interest of scholars with its grammatical specificity and has been a controversial unit when viewed comparatively especially in the socially contacted the Ukrainian and English languages.

The scientific value of contrastive studies has substantial grounds in the context of cross-linguistic development focusing on theoretical (metalinguistic) interpretation of language units and their actual (speech) interaction (Amr M. El-Zawawy, 2016; Defrancq, 2015; Koning, 2012). Modern comparative linguistics is considered to be a complex area of study comprising different fields (comparative and historical, typological, universal linguistics). The Eastern scholars recognise the independent status of contrastive linguistics regarding it as an autonomous sector of comparative studies (Kocherhan, 2006, p.45). The importance of identifying semantic universals and conceptual distinctions in languages has been mentioned by well-known linguists (Kayne, 2010; Krzeczowski, 1991). Nowadays, scholars have been discussing the appropriate approaches and methods to compare linguistic units and phenomena (Wen'guo, 2007 , p. 287). It is obvious that verbs as a class must differ from language to language, but they have enough common grammatical features across the languages to merit the shared label. These shared features are of various kinds, and different ones are highlighted by different scholars (Cruzo, 2016; Fathy Khalifa, 2018).

So this article suggests the way of a cross-linguistic study of verbs in English and Ukrainian from the bilateral contrasting perspective. Our theoretical research is aimed at creating the model suitable for bilateral 
comparison of the verb's systems in the compared languages for identifying similar and divergent means of the meaning of process.

\section{The benefits of contrastive cross-linguistic approach}

To start a discussion, it is necessary to point out that cross-linguistic studies from a contrastive perspective have great advantages over other approaches to language comparison. In the early stages of the development of the field, comparisons were usually carried out with a view to applying the findings for the benefit of the community, for example in foreign-language teaching or in translation (Fathy Khalifa, 2018; Filipovic, 2017; Willems, 2004). In recent years, this applied orientation has been complemented by a growing body of contrastive research with a more theoretical orientation. As Jalilbayli (2015) claims, "comparative study of language objects is a characteristic feature of modern linguistic investigation. At mutual correlation and confrontation of language units, forms, categories and so on, their specific peculiarities are exactly discovered" (p. 137).

Contrastive approach declares the benefits that are caused by several factors: 1) the possibility of comparing the minimum number of languages (often two) in order to correlate them with the maximum of language markers (structural, semantic, functional) that are relevant for a synchronous state of the studied languages; this is opposed to linguistic typology that focuses on the maximum languages correlating them with a minimum of universal structural features; 2) the probability of studying any language unit and levelto-level phenomena in various aspects with the use of scientifically relevant approaches to contrastive analysis; 3) the ability to reveal such features of correlated languages that remain out of sight and are observed by direct "overlapping" of language systems on the estimating basis of comparison; this is actually the linguistic motive of the comparative approach; 4) the importance of the revealed similarities and differences for both theoretical understanding and deeper knowledge of linguistic patterns, and cross-cultural communication. In other words, contrastive analysis helps shift from a special focus on genetic factors (crucial for comparative and historical studies) as well as avoid focusing on the pointed lists of distinctive features and languages (important for characterology and typology). Nevertheless, such a "simplicity" of contrastive analysis actually demands quite a complex methodological procedure meant to identify not only common (isomorphic, identical), but also divergent (specific, allomorphic) characteristics of the selected object in each language under comparison. In fact, contrastive studies also provide a basis for further typological generalisations (Ivanytska, 2013).

\section{Ukrainian and English verb's systems from the contrastive perspective}

In this regard, it is exceptionally significant that Ukrainian and English verb's systems are under indepth study and still open for comprehensive lexical-semantic and grammatical contrastive analysis from the contrastive perspective.

To start a cross-linguistic Ukrainian and English verb's systems comparison we are consistent with some key guidelines: (1) current tendencies in intralanguage theoretical background of verbs with their deliberate "adaption" to the methodological approach are deeply considered, (2) the principle of consistency seems to be significant for the cross-language comparison, (3) two-way (bilateral) approach to comparison is a more powerful research tool (Kocherhan, 2006, p. 36). The latter is really crucial for scientific work due to the following: (1) the interference of the language A to the language B image is avoided and the compared languages are believed to have identical statuses; (2) foreign language(s) and culture(s) are not studied in the light of native languages. The bilateral approach determines the substantiated choice of the basis of comparison (tertium comparationis) that is considered to be a special metalanguage construct.

\section{Bilateral vs unilateral contrastive study}

The answer to the key question "How to build the best way for comparing language units?" is rather comprehensive. Traditionally scholars distinguish between a unilateral (one-way) and bilateral (two-way) comparison. The principal differences between these approaches are in identifying a notion intended to be a tertium compationis (basis of comparison).

The unilateral approach is quite sufficient for applied linguistics, especially for language teaching and translation theory. However, the theory of language needs another approach for estimating cross-language similarities and differences. The priority now is given to the bilateral approach to cross-linguistic comparison that enables them to validate a conclusion by using "an objective, extra-language unit" (Kocherhan, 2006, p. 56), "a set of notions that exists regardless of individual languages, and is taken hypotheticallyheuristically" (Wierzbicka, 1996, p. 34), "unified language as a set of abstracted notions that help to interpret the structure of most languages without reference to their typological differences" (Vogel, 2000, p. 147). 
Most scholars are fully confident that a tertiun comparationis should be an initial basis for comparison. Being general and universal, it can serve as a specific standard, an indicator of the adequacy of structural language characteristics (Ivanytska, 2013). We can view the tertium comparationis as a certain scientific artefact that helps to establish systems of identities (a kind of equivalent phenomena).

It is essential to consider that providing a certain unit with a status of tertium comparationis is determined by (1) the units chosen for contrasted comparison, (2) their place and role in the language system, (3) the completeness of their intralinguistic a priory knowledge, (4) defined goals and tasks of comparison, (5) a methodological framework, (7) typological features of compared languages.

\section{Categorisation in linguistic theories}

Comparing the verb's systems in the Ukrainian and English languages, it is necessary to proceed from the point that a language is a primary means of communication, closely related to social production and cognitive activities of people (Plungyan, 1998, p. 49). It is a semiotic system that expresses the ratio between the elements of reality and their reflections in the minds. In this case, the tertium comparationis can be defined as a generalised linguistic verb (semantic and grammatical) category. This category is an "umbrella notion" (a term that provides a super-set of grouping of related semantic and grammatical aspects) expressing complicated categorical characteristics of the compared Ukrainian and English verbs (Ivanytska, 2011, p. 34).

It should be emphasised that categorisation is one of the most fundamental concepts of human consciousness. It is a theoretical model of the human world perception reflected by words meanings. Linguistic category is supposed to be the most general concept resulting from abstraction of objects and their distinctive characteristics (Plungyan, 1998, p. 49).

It is not without a reason, that scholars hold views that cognition is always asymmetric. Human beings tend to perceive "some fragments of reality as if through a magnifying glass, and others - as if through inverted binoculars" (Plungyan, 1998, p. 50). Categorical meanings and categories formed on their basis are considered to be the meanings that are perceived through a magnifying glass due to their significance for creating a national language worldview. The system and structure of grammatical categories are the key points in the language structure as they reflect the specific relationship between language, mind, and typological features of individual languages and language groups.

We claim that contemporary linguistics qualifies the category as "one of the central key notions in a language theory (along with the form, meaning and function)" (Hallidey, 2002; Wierzbicka, 1996). The phenomenon of categorisation covers all the levels of the language system within which there are various categories.

The category of "process" as tertium comparationis of Ukrainian and English verb's systems. Providing the verbal category "process" with the status of tertium comparationis, we qualify it (like the majority of other verbal categories) as a generalised abstract model that has its realisation in a dual way: semantically and grammatically. Semantic and grammatical aspects of the category "process" have a complicated nature. The results of a theoretical study of the verbs based on the methods of logical semantics, onomasiology, cognitive science and functional grammar prove that the category "process" has functionalsemantic backgrounds. This approach makes it possible to create the functional-semantic fields filled both with verbal lexemes, and multiword nominations of the action/state. Generally they suggest them to be an alternative representation of the language system as compared with a traditional level language model.

There is no doubt that pragmatic (communicative-functional), as well as cognitive, psychological, and ethnic approaches to the typology of parts of speech have built a strong ground for functional identification of the verbs in different languages. The results of these scientific works seem to be promising for the language theory improvement. However, we hold the view that Eastern scholars do. They believe that the category of "process" comprises only one-word nominations. This approach is more prominent for a bilateral cross-linguistic comparison. It allows us to build a more objective framework for comparative analysis by way of: 1) focusing on single-level linguistic units, (2) following the principle of systematic contrastive researches, 3) using the correlated theories of intralanguage studies, 4) focusing on the comprehensive crosslinguistic study comprising lexical-semantic paradigms and formal syntax syntagmatics.

The complicated structure of the category "process" makes it possible to distinguish some kinds of mini-tertium comparationis that are considered to be relevant for different aspects of contrastive studies of the verbs. 


\section{Semantic aspect of the category "process"}

It should be noted that a semantic aspect of the category "process" has the ontological nature. It allows correlating verb nominations and extralinguistic reality, so-called processing denotata. Such nominations (one-word or more than one-word) in their projection on the identical denotata are believed to be comparable. Comparability involves identifying not only contrastive differences of compared units, but also their identities, complete or partial correlations. Thus, we consider equally comparable both separate verbs (читати - to read, бігати - to run, їсти - to eat), and Ukrainian phrases and English one-word nominations (готувати їжу - to cook, працювати медсестрою - to пиrse, продавати з аукціону - to auction, класти в мішок - to bag, записувати в книжку - to book, їхати автобусом - to bus, etc.).

Lexical-semantic paradigms of the Ukrainian and English verb's systems are represented by the most significant fragments being defined as subcategories: "processing action", "processing state", and "processing relation". These subcategories have a ranking structure. They are formed by a number of microcategories like "action-sound", "action-movement", "action-professional activity", "state-psychological state", "state- physiological state", etc. (Ivanytska, 2011, pp. 128-352).

These microcategories are considered to form the correlated lexical-semantical fields. The central and peripheral parts of these fields, being filled with the Ukrainian and English verbs, reflect some common and specific ways of the classification of reality concepts. The gaps in the cross-language fields are caused by two factors: extra-linguistic and, not the least, interlanguage structural laws. To prove this idea the instance is given. The semantic field "action for movement" in English contains verbs with the meaning "to operate a vehicle so that it goes in a particular direction": to balloon, to bicycle, to bike, to boat, to bobsled, to bus, to cab, to canoe, to caravan, to chariot, to coach, to cycle, to dogsled, to ferry, to gondola, to helicopter, to jeep, to jet, to kayak, to moped, to motor, to parachute, to punt, to raft, to rickshaw, to rocket, to skate, to skateboard, to ski, to sled, to sledge, to taxi, to toboggan, to tram, to trolley, to yacht, etc. The semantic analysis of these English verbs has brought to light a distinguishing seme "vehicle" in the semantic structures of the verbs. The seme is unique for English and can be specified by vehicle names: to bicycle "to ride $a$ bicycle"; to boat "to go by boat"; to bus "to travel by bus"; to helicopter "to travel by helicopter"; to raft "to travel by raft"; to yacht "to manage a yacht, to voyage in a yacht", etc. (Cambridge Dictionary on-line, n.d.). One can notice the lack of such verbs in the Ukrainian language where they use analytical nominations like ӥхати автомобілем, пливти човном, etc. The methodological background for providing bilateral contrastive analysis makes it possible to reveal the systematic lacunas (gaps) in the realisation of the category "process". Thus, the correlative and lacunative areas of semantic paradigmatics of the universal verb's category of process can be delineated.

Another example of the effectiveness of using a bilateral comparison for revealing differences in the systematic semantic paradigms of Ukrainian and English verbs is given. We can build the semantic fields of a microcategory "action for creating an object". The sematic and comparative analysis reveals the seme "cooking" in the semantical structure of these verbs. The concretisation of this denotative situation is rather different in the compared languages. The Ukrainian language doesn't categorise an action having such verbs as смажити, жарити. On the contrary, English verbs are considered to be more specified and are viewed as lacunative regarding Ukrainian equivalents. Their semantics contains such aspects as: 1) opening the fire and its strength (to broil - смажити над відкритим вогнем; to fry - смажити на сковородi; to roast смажстти на відкритому вогні; to grill - смажити на металевій решітиі); 2) the degree of frying (to frizzle - смажсти із шкварчанням до утворення хрусткої скоринки); 3) the amount of fat (to panfry смажити в невеликій кількості масла; to panbroil - смажити без жиру); 4) the source of heating (to charcoal, to charbroil - жарити на вугіллях), etc.

\section{Grammatical (syntagmatic) aspect of the category "process"}

To determine syntagmatical correlative and lacunary relations of Ukrainian and English verb's systems, we focus on the following aspects: (1) syntagmatic stratification of the verbs as notional lexemes, (2) formalisation of syntagmatics, and (3) a clause-generating potential of the Ukrainian and English verbs related to the identified microcategories (Ivanytska, 2011, p. 354).

Each aspect presents formal macrocomponent of the universal verb's category "process". The combinability of the verb can be regarded as an ideal model for determining syntagmatic correlation between Ukrainian and English verb's systems. The verb's combinability can be expressed through subordination.

The force of this subordinative connection has become a criterion for the mandatory / non-mandatory use of a verb and distinguishing between autosemantic / synsemantic units. Comparison of the autosemantic / synsemantic verbs can show their correlation in capability to nominate procedural denotations. 
We can typify cross-linguistic syntagmatic correlations between the Ukrainian and English verb's systems by correlative explicators as formal indicators of absolutely identical, partly shared or absent correlations of verb's syntagmatics. We identify correlation indicators in syntagmatic ranks and qualify them as non-verbalised and verbalised. We delineate verbalised explicators into: unpredicative / predictive / semipredictive; synthetic / analytical; simple / complicated; one-position / multiple positions.

On the other hand, a simple verbal sentence structure model as a basis for comparison can reveal the clause-generating potential of Ukrainian and English verbs systems. Among different views on the sentence and the concept of a "model clause" in Slavic and German linguistics one comes across the opinion concerning the difference between the concepts of "predicative minimum sentences" and "nominative minimum sentence" (Ivanytska, 2011, p. 367). We stick to the opinion that using the nominative minimum sentence as an extended framework is more reasonable for a contrastive study. We view it as a pattern containing the minimum sentence diagram (major components) and obligatory word redistributors that are necessary to implement the sentence nominative function. We distinguish the verbal sentence structures models from reliance on verbal syntagmatic properties and rank it by distributive features of verbs, combined with generalised syntactic semantics of syntagmatic explicators. Thus, we can establish the typology of simple verbal sentence models. The usage of such typology appears to be a reliable basis for important contrastive and comparative research results in the process of establishing syntagmatic correlation between Ukrainian and English verbs systems.

To prove the idea there is an example. The correlation of the verb's systems can be determined taking into consideration the predicative model of state as mini-tertium comparationis used for verbal syntagmatical peculiarities. The model is realised in speech by authosemantic verbs with state semantics: Зійило сонце; Настав вечір; Засідання закінчилось; Руки потерпли; Похід спинився (Л. Костенко); англ. Нег еуеs twitched and burned (J. Morrison); Nicolas laught aloud (R. Stevenson); Catherin blushed (E. Hemingway); When the food is cooked it becomes less structured so its entropy grows (V. Marzeniuk); At a full in the entertainment the man looked at me and smiled (F. Fitzgerald).

The specific functioning of such models is determined by the "close" nature of the verbs which have no need to generate obligatory positions for dependent words. The Ukrainian authosemantic verbs have a wider semantic variety to compare with English equivalences. This fact has a great influence on the structural correlation between realisations of a predicative model of state. Besides, the Ukrainian verbs have capacity to realise the model without naming the subject causing the existence of a so called impersonal sentence and predicting deviations in correlation in contrastive verbal syntagmatics. Thus, the research reveals a correlative relationship in the compared languages. The differences are also valid for the theory of a language. We can reveal a number of divergent facts that specify the model due to the syntactic structure of each language.

Using the sentence model as tertium comparationis for establishing a syntagmatic correlation between Ukrainian and English verbs systems helps elaborate a fact that Ukrainian patterns are more specific in cases when a verb is reflective or aspectual. We can see that English verbs have more generalised meaning while Ukrainian verbs are more specific: Склянка розбилася - A glass broke; Крісло зламалося - A chair broke; Мотузок розірвався - A rope broke; Лід тріщить - The ісе breaks; укр. Бруньки розпускаються - The buds break; укр. Дош перестав - The rain broke; Погода змінютться - The weather is breaking; Надходять сутінки - The darkness breaks.

\section{Conclusions}

To sum up, cross-linguistic studies have been perspective for contemporary linguistics. We consider contrastive approach focused on identifying language peculiarities without references to their genitive and typological groups as promising for revealing language divergence. The scholars traditionally differentiate between unilateral (one-way) and bilateral (two-way) approaches to the contrastive analysis. The bilateral approach is more efficient for the theory of language. The crucial point of bilateral contrastive analysis is providing the extra linguistic unit with the status of a tertium comparationis. The chosen non-linguistic concept is determined deductively and we can determine it as a metalinguistic unit.

To make a comprehensive contrastive analysis of Ukrainian and English verbs we find it reasonable to give a status of tertium comparationis to the verbal category of "process". We have the actual reasons to make this choice: 1) we believe that the category is an extra-language notion with a general meaning; 2) the category has a valid theoretical intralanguge treatment; 3) it can be trusted because of its capacity to comprise and unite lexical semantics and grammar; 4) the category can easily project meaningful for contrastive study verb's characteristics that makes them comparable. 
Thus, the category of "process" is qualified as a generalised abstract model that possesses a comprehensive nature and dual representation - by lexical semantics of verbs, and by a set of grammatical (morphological, derivational, syntactic) categories.

The usage of the verb's category of "process" as a tertium comparionis enables scholars to get comprehensive results due to its integrity. The semantical projection of this category on the verb's paradigms makes it possibly to find out systematic inter-linguistic as well as intra-language lacunas.

The contrastive analysis of syntagmatic peculiarities of Ukrainian and English systems which are mapped with the category of "process' as a tertium comparationis is insured by syntagmatic capability of the verbs. The autosemantics and synsemantics of the compared verbs are relevant and challenging for scholars. A clause-generating potential of the Ukrainian and English verbs is also of great significance. We concern the verb patterns (the nominative minimum sentence) are reliable for identifying similarities and differences in verb's syntagmatics. Such patterns serve as a special tool for establishing correlation between Ukrainian and English verbs. The process of creating sentences of different structures is based on the verb's valence and grammatical traditions of the synthetic Ukrainian and analytical English languages.

\section{References:}

Aarts, B. \& Meyer, C. (2006). The verb in contemporary English: theory and description. Cambridge University Press.

Amr M. El-Zawawy (2016). Studies in Contrastive Linguistics and Stylistics. Nova Science Publishers, Incorporated.

Baker, M. C. (2003). Lexical categories: verbs, nouns, and adjectives. Cambridge University Press. https://doi.org/10.1017/cbo9780511615047

Defrancq, B. (2015). Contrasting contrastive approaches. Language in contrast, 15, 1-3. https://doi.org/10.1075/lic.15.1

Deshors, S. (2017). Zooming in on Verbs in the Progressive: A Collostructional and Correspodence Analysis Approach. Journal of International linguistics, 45 (3), 260-290. https://doi.org/10.1177/0075424217717589

Cambrige Dictionary on-line (n.d). Retrieved May 10, 2018 from: http://dictionary.cambridge.org/

Cruzo, O. \& Hansen-Schirra, S. (2016). Crossroads between contrastive linguistics, translation studies and machine translation: TC3-II. Berlin: Language Science Press.

Fathy Khalifa, M. (2018). Contrastive Analysis, Error Analysis, Markedness Theory, Universal Grammar and Monitor Theory and their Contributions to Second Language Learning. International Journal of Linguistics, 10, 1, 12-41. https://doi.org/10.5296/ijl.v10i1.12479

Filipovic, L. (2017). Applying typological insights in professional practice. Language in contrast, 1, $255-278$. https://doi.org/10.1075/lic.17.2.05fil

Halliday, M. A. K. (2002). Some aspects of systematic description and comparison in grammatical analysis. In J. Webster (Ed.), On grammar. Collected works of M. A. K. Halliday (Vol.1, pp. 121-36). London: Continuum.

Haspelmat, M. (2016). The Serial Verb Construction: Comparative Concept and Cross-linguistic Generalizations. Language and Linguistics, 17(3), 291-31. https://doi.org/10.1177/2397002215626895

Ivanytska, N. (2011). Diieslivni systemy v Ukrainskii ta angliiskii movach: paradygmatyka ta syntagmatyka [Verbal Systems in Ukrainian and English: paradigmatics and syntagmatics]. Vinnytsia: Nova knyha.

Ivanytska, N. (2013). Dvobichnyi zistavnyi analiz ukrainskoi ta angkiiskoi diieslivnykh system (Bilateral contrastive study of Ukrainian and English verb systems). Philology. Linguistics, 216, 40-44.

Kayne, R.S. (2010). Comparisons and contrasts (Oxford Studies in Comparative Syntax). Oxford: Oxford University Press.

Kocherhan, M. (2006). Osnovy zistavnogo movoznavstva [Basic Contrastive Linguistics]. Kyiv: Academiia.

Koning, E. (2012). Contrastive linguistics and language comparison. Language in contrast, 2, 3-26. https://doi.org/10.1075/lic.12.1.02kon

Krzeszowski, T. (1991). Contrasting languages: the scope of contrastive linguistics (pp.134-137). Berlin: Walter de Gruyter. https://doi.org/10.1515/9783110860146

Levin, B. \& Rappaport, M. (2005). Argument realization (pp. 278-279). Cambridge University Press. https://doi.org/10.1017/cbo9780511610479

McMillon, A. (2006). Verbs in English. Their Meaning, Behaviour and Structure (pp.123-124). Cambridge University Press.

Ogtay B. Jalilbayli (2015). Category of Tenses of Verbs in the Azerbaijanian and Japanese Languages International Journal of English Linguistics, 5, 5, 136-146. https://doi.org/10.5539/ijel.v5n5p136

Palmer, F. (1987). The English Verb. Second edition. London: Longman

Plungyan, V., (1998). Grammatical Categories, their Analogues and Substitutes (pp.49-50). Moscow.

Syleymanova, K. (2015). Text Forming Potentials of Verbs. International Journal of English Linguistics, 5, 153-155. https://doi.org/10.5539/ijel.v5n5p153

Vogel, P. \& Comrie, B. (Eds.) (2000). Approaches to the typology of word classes. Empirical Approaches to Language Typology, 23, 146-149. https://doi.org/10.1515/9783110806120

Wen'guo, P. \& Tham Wai Mu (2007). Contrastive Linguistics: History, Philosophy and Methodology. Continuum. https://doi.org/10.5040/9781474211802

Wierzbicka, A. (1996). Semantics. Oxford University Press.

Willems, D, Defrancq, B., Colleman, T., \& Noel, D. (Eds.) (2003). Contrastive Analysis in Language Identifying Linguistic Units of Comparison. Palgare Macmillan. https.//doi.org./10/1057/9780230524637 